\title{
What is the Best Strategy to Obtain Legislative Support? Survey Evidence from Brazilian State Assemblies*
}

\author{
Felipe Nunes \\ Department of Political Science, University of California, Los Angeles
}

\begin{abstract}
The legislative success of governments in Latin America has been explained by two main theories. For some authors, the main explanation involves the proactive and reactive powers of the chief executive. Other scholars argue that negotiations with deputies for portfolios and pork are the most important factors behind success in approving legislation. This paper proposes an innovative methodological strategy to test the mechanisms behind each of these theories. Original survey data of 12 Brazilian state-level assemblies is examined to assess elites' attitudes in regard to governors' strategies to obtain legislative support. Results suggest that there is not a unique equilibrium to the problem of coalition formation in multiparty settings. Deputies with concentrated constituencies, from more decentralized parties, and from conservative parties, tend to believe that the most efficient way a governor can obtain legislative support is to negotiate amendments with deputies. On the other hand, the more scattered a legislator's constituency and the more liberal or centralized his or her party, the more likely a deputy is to think that governors achieve better legislative success when they negotiate cabinet positions.
\end{abstract}

Key words: Executive-Legislative relationship; subnational politics; survey data; legislators' attitudes.

* A previous version of this paper was presented in the 21th World Congress of Political Science, 2009, in Santiago, Chile. The research was supported by a master fellowship from FAPEMIG, and two research grants from FAPEMIG and CNPq. I would like to thank Dalson Figueiredo Filho, José Alexandre Silva, Magna Inácio, Fátima Anastasia, Marta Mendes, Steve Palley, and Paasha Mahdavi for their comments and suggestions. I also would like to thank the two anonymous reviewers, the BPSR editors, and Sandra Gomes for their valuable reviews and feedbacks. Replication files can be find at http://felipenunes.bol.ucla.edu. Responsibility for any error or omission lies solely with the author. 


\section{Introduction}

The legislative success of governments in Latin America more broadly, and in Brazil in particular, has been explained by two main theories. For some authors, the main explanation involves the proactive and reactive powers of the chief executive, which gives him a central role in formulating and conducting the government's agenda (Aleman and Tsebelis 2002; Figueiredo and Limongi 1999; Morgenstern 2004; Santos 2003;). Other scholars believe, however, that negotiations with deputies for portfolios and pork - along with the need to form coalitions and cabinets - are the most important factors (Altman 2000; Ames 2001; Amorim Neto 2006a; Amorim Neto and Santos 2003; Inacio 2006; Nunes, 2011; Pereira and Mueller 2004; Raile et al. 2010; Zucco Jr. 2009). Although these approaches have contributed to the understanding of political reality in many places, I propose here an innovative methodological strategy to test the mechanisms behind each of these theories.

Instead of observing how legislators vote when the government presents its agenda, I evaluate the conditions under which legislative support may be obtained based on elites' attitudes in regard to governors' strategies to obtain legislative support. The paper, therefore, does not intend to explain the degree of legislative success of presidents or governors, but presents empirical evidence showing that success varies considerably because legislators' attitudes to the executive also vary. In accordance with Power and Zucco Jr. (2011), I also believe that the views of parliamentarians give us an unique interpretation of the behavioral data we have access to. In their own words, "although revealed preferences are often more reliable than stated preference, the views of parliamentarians can tell us about the interpretation of the behavioral data. After all, self-perceptions of legislators and their evaluations of the national political reality enable a rich contextualization of the behaviors observed in the floor." (Power and Zucco 2011, 10)

I believe successful negotiations occur when the governor can offer legislators and political parties the resources they care most about. It is not accurate to assume that there is only one strategy that would appeal to all legislators. As deputies have different electoral backgrounds and are members of different party organizations, one could suppose that such features would determine the preferences of each actor, and therefore, his behavior. A successful chief executive should realize that different legislators need different resources. What I propose in this paper is a research design to evaluate which legislators' features would produce an easier (or harder) setting for executives intending to approve their agendas based on legislators' attitudes. Such an idea cannot be assessed by behavioral data, but can be approximated by surveys with legislative elites. To accomplish this, I have collected data from a survey rolled in twelve Brazilian subnational states between 
2007 and 2008. ${ }^{1}$ Therefore, I was able to identify the stated preferences of legislators - as expressed in their opinions - which should suggest how Brazilian governors would get the biggest "bang for their buck" when they offer partners the resources that maximize their expected votes. ${ }^{2}$

Given that politicians care greatly about electoral success, and that they only have their time in office to convince voters to support them, I argue that the degree to which a legislator is convinced to support the governor's agenda depends on the governor's ability to give him or her a "great deal" - meaning that the offer matches up and satisfies that legislator's demand. That is, the success of a government will depend on the capacity of a governor to (1) find information on the desires and needs of his or her potential allies, (2) distribute and/or share political power and resources according to this information, and (3) dictate how resources will be offered to his or her allies. In the investigation, I identify patterns that could explain why certain coalitions happen to be successful, while others fail. ${ }^{3}$ This is not to say that attitude data is superior to behavioral data, but simply that the complementation of each other produces a wider perspective.

The first task in this empirical project is to check whether there is, in fact, variation among legislators' perceptions of the utility of different political resources controlled by the governor. More specifically, I investigate whether legislators prefer to receive one kind of resource instead of another from the chief executive. After that, my focus shifts to identifying which features of legislators and political parties influence deputies' opinions about their relationship with the Executive. I use a Multinomial Logit Model to estimate the effect of (1) the type of the deputy's constituency, (2) the degree of the deputy's party centralization, and (3) the ideological position of the party of which the deputy is a member has on that deputy's opinion of "the best strategy that a governor can pursue to obtain legislative support." I find that there is no unique solution to the problem of coalition formation in multiparty settings. In fact, the chief executive must find an ideal strategy for different kinds of players, and this is what makes the strategic game between them so interesting to study.

In sum, my results show that members with concentrated constituencies, from more decentralized parties, and from conservative parties, tend to believe that the most efficient way a governor can obtain legislative support is to negotiate amendments with deputies. On the other hand, the more scattered a legislator's constituency and the more liberal or centralized his or her party, the more likely a deputy is to think that governors achieve better legislative success when they negotiate cabinet positions. 


\section{Institutions, Resources, and Governability}

The Brazilian institutional arrangement often requires the Executive to build governing coalitions. ${ }^{4}$ However, forming a coalition is not a sufficient condition for governments to rule. First of all, in the sample space of all possible types of coalition formation in multiparty systems, some arrangements simply will not work. Moreover, minority governments can also succeed in getting their agendas approved (Laver and Schofield 1990; Saiegh 2004). Nevertheless, if most governments in Brazil since 1988 have taken the form of party cabinet (Amorim Neto 2006b), it is reasonable to assume that presidents share their resources expecting that allies participating in the cabinet will, in turn, support his or her agenda in the legislature. This general idea has been called "presidencialismo de coalizão" (Limongi 2006). Although there is a high degree of explanatory power behind this reasoning, no analyses of the Brazilian case have considered the constraints involving the exchange of political resources for legislative support. ${ }^{5}$

This is an important point, as the use of strategies to mobilize political or budgetary resources strongly depends on the relationship between the government's agenda and the preferences of the actors in play. As Cheibub et al. (2004) have shown, a chief executive will only have incentives to share power if the preferences of the actors needed to achieve a majority and approve the agenda do not match those of the executive. The authors call the attention to the negotiation over the content of policies voted in the legislature. If the parties agree on a certain topic, then the president may not need to negotiate patronage or pork with deputies/parties in exchange for support of that policy. The ideological position and the preferences of the political party will determine the likelihood of a deputy to support the policy in question.

Assuming that the political distance between political parties is given, the work of Amorim Neto (2006b) builds on our knowledge of the connection between presidential success and the operational conditions under which it is achieved. The author discusses the main incentives motivating an actor (individual or collective) in a coalition cabinet. According to Amorim Neto, the distribution of offices in the cabinet will depend on the volume of the resources mobilized by the president, the power of the Legislative against the Executive, and the individual legislator's ability to pursue an Executive position without losing his or her opportunity to win future legislative elections. Amorim Neto's expectations vary depending on features inherent to the negotiation.

First, to have an efficient bargain, the governors' offer to actor $X$ must correspond with the expectations raised by $X$. For instance, one cannot convince a liberal legislator to join one's coalition by talking to him or her about conservative proposals. The same logic holds for the disbursement of resources. Unfortunately, it is often very hard to identify the 
true preferences of the actors involved in such negotiations. The literature has used roll call votes in an attempt to measure such preferences, but I do not believe this is the only strategy that should be used. Roll calls express the strategic behavior of political actors ex post facto, after they have gone through the negotiation-persuasion phase and may have already gained other political goods from the executive in exchange. Thus, they may not accurately measure the actors' true preferences. In this paper, I propose a new methodological solution to this problem. My assumptions are that a legislator's preferences are given, and they will try to maximize their expectations given their preference ordering. The challenge is to identify what determines a legislator's preferences.

Studies have postulated that political parties have three main types of objectives in modern democracies: votes, offices and policies (Strom 1990; Mueller and Strom 1999). However, the most interesting finding of such models is the interaction among each of these dimensions. Building on Strom's arguments, I posit that it is in the interest of parties, after they reached office, to obtain pork and policies that are compatible with their constituency's preferences. Therefore, I expect that a member's propensity to support the government in the legislature is directly related to the sort of resources they are offered by the governor. In other words, the preferences of legislators are constituted and constrained by their constituencies' preferences.

However, political parties are also the source of preferences for legislators. Legislators come together in a party through a shared interest in office (Aldrich 1995) when they agree on policy (Cohen et al. 2008). Thus, the preferences of individual legislators will reflect the ideology shared by the group that constitutes their party, either locally or nationally. As several papers have shown, ideology is still a key distinguisher of politicians in Brazil (Castro et al. 2009; Power and Zucco Jr. 2009), although ideology's influence on roll call votes has diminished over time (Zucco Jr. 2009). Thus, it is reasonable to believe that ideology is still a good proxy for what legislators wish for.

Second, obtaining the support of player $\mathrm{X}$ depends on the way that the government negotiates with $\mathrm{X}$. The difference between hierarchical or horizontal relationships can often determine the satisfaction with a job or a deal (Glisson and Durick 1988). Thus, the manner a negotiation is pursued can influence whether an agreement is ultimately obtained. More often than not, however, the most important determinant of success is not the approach of the negotiation, but rather the formal and informal structures of the organization in question (Campbell et al. 2004). In the government case, the internal organization of each party, the party system, and the degree of legislative centralization constrain the president's negotiation strategies. Strong party systems tend to generate more programmatic negotiations between the players in the competition (Sartori 1987). Under such conditions, elections become contests about ideology, and as such, they are organized 
around party platforms. Voters can distinguish between parties because they clearly represent different political projects (McCarty et al. 2008).

Regarding political parties, the more centralized they are, the larger their staff, the higher their internal cohesion, and the more important party leaders will be, therefore, they will intervene more in negotiations (Cox 2005; Mair 2006). According to Mair (2006), parties will become weaker in the electoral arena but stronger in the parliamentary arena under these conditions. This empowerment of parties in the legislature made the larger parties inclined to enlarge their programmatic connections and to enrich their internal structure, giving more coordination capabilities to party leaders. Cox (2005) shows how the "state of nature" in legislatures has bad implications for a government's functionality: without coordination by party leaders and chairs, Congress tends to be held hostage by filibusters. Thinking of the legislature as a company, as suggested by Weingast and Marshall (1988), leads many legislatures to try to create an institutional structure that can generate gains through trade in a continuous decision-making process with low transactional costs (North 1990). This may result in a robust link between the structure of parties and the preferences of legislators for various kinds of political negotiations.

Finally, when making deals, the relationship between legislators and the executive is dependent on the ideological position of the actors in the negotiation. A one-dimensional ideological spectrum is the classic structure used to understand political behavior. I believe that it helps to understand the phenomenon that is analyzed here in two ways: first, parties from different ideological orientations tend to have different types of constituencies (Ames 2001; Carvalho 2003; Nunes 2009; Zucco Jr. 2009); second, coalitions with parties that are closer ideologically tend to produce more consistent and long-term legislative results. As Iversen and Soskice (2006) show, center-left governments dominate under PR systems, and they also tend to redistribute more. The mechanism behind the argument is that coalitions representing the poor and the middle class are easier to be formed in proportional representation systems than in majoritarian ones. So, it is reasonable to believe that constituencies of left-centered governments are different from the constituencies of right-centered governments. The position of the partners along the one-dimensional spectrum also matters. As argued by Inacio (2006), coalitions in which the inclusion of participants was based on the smallest ideological distance, and were constructed ensuring a minimum enlargement of the cabinet, demonstrate higher presidential legislative success. Under these circumstances, it is easier to solve coordination problems that result from the heterogeneity of the players' preferences. 


\section{Opinions about Coalition Formation Strategies}

What the literature has forgotten so far, however, is that what is negotiated and how it is negotiated between the Executive and the Legislative may depend on certain factors that may be a function of a legislator political profile and/or a party organization. To assess potential features that might determine how a coalition should be composed, I will use attitude information based on a survey applied to the political elite. In summary, I claim legislators' constituency types and ideological positions dictate the type of resources they care most about, while the degree of centralization adopted in their political parties influences their preferences for the form of negotiation with the executive. Such theoretical expectations should be investigated empirically in order to check their validity.

Instead of observing directly, I will investigate such associations based on deputies' stated preferences and characteristics. I also believe that parties and the individual attributes of parliamentarians impact the structure of their preferences. Therefore, my analytical strategy will be to search for connections between these member's features and their opinions is based on a survey conducted in 12 Brazilian Assemblies. If variation within and between the states in parliamentarians' opinions about the efficiency of the governors' strategies in obtaining legislative support is found, I expect this will be associated with his or her electoral-party profile.

The electoral-party profile of parliamentarians refers particularly to (1) his or her constituency, (2) the degree of centralization of his or her political party, and (3) the ideological position of the party he or she is a member. I expect that a variation of these three dimensions will affect the parliamentarians' opinion on the efficiency of the governor's strategies in the following directions:

- Hypothesis 1: if a deputy with a geographically concentrated constituency prefers to send particularistic benefits for his/her electoral supporters, then we should expect this kind of deputy to believe the most efficient way to obtain his/her legislative support is to give him/her pork or jobs. On the other hand, we should expect deputies with scattered or universal constituencies to believe that the most efficient strategy to obtain legislative support by the governor is to form a multiparty cabinet negotiated with party leaders.

As Nunes (2011) has shown, deputies with concentrated constituencies tend to have leverage over pork appropriations in Brazil, given their ability to claim credit for investments made in their constituencies. Legislators with scattered constituencies, on the other hand, use pork appropriations as a marginal tool to pursue electoral success. Thus, it is 
expected that the propensity of members to support the government in the legislature is directly related to the kind of resources offered to them by the governor. In other words, the preferences of legislators will be constituted and constrained by their constituencies' preferences and composition.

- Hypothesis 2: if a conservative deputy tends to be associated with groups that demand targetable goods instead of universal policies, then we should expect this kind of deputy to believe the most efficient way a governor might get legislative support is through the negotiation of pork appropriations with each legislator; whereas deputies positioned on the left side of the ideological spectrum should believe that the most efficient strategy to form a multiparty cabinet is to negotiate with party leaders.

It is reasonable to believe that ideology is a proxy for what legislators want in legislatures. Left-wing parties, as representatives of groups in society, should prefer negotiations based on policies that involve appointments to the cabinet, while conservative parties, as an organization of politicians, should prefer pork appropriations for their constituencies.

- Hypothesis 3: if legislators who are members of a decentralized party tend to have more flexibility and freedom to act as independent politicians, then we should expect them to believe the most efficient way a governor can get legislative support is through the negotiation of pork appropriations with individual legislators, whereas deputies members of centralized parties should believe that the most efficient strategy is the composition of a multi-party cabinet negotiated with party leaders.

When referring to political parties, the following reasoning applies: the more centralized they are, the more important party leaders will be, and therefore, the more they will intervene in negotiations (Mair 2006; Cox 2005). These conclusions should lead us to expect that cabinets will be formed when leaders are decisive and strong in controlling their benchmark behavior, while pork will be determinant when parties are decentralized and undisciplined.

Although these hypotheses are presented as separate options, I also treat them in interaction with each other in the empirical test. By doing so, I expect to observe which systematic effects are due to exclusive or complementary interaction of variables. I believe, for example, that the importance of a leader to the composition of a cabinet could annul the effect of ideology when a leftist legislator is a member of a centralized party. 


\section{The Survey}

The data that will be used to test the relationship between legislators' perception on coalition formation strategies and legislative support was collected in twelve subnational Brazilian Assemblies between 2007 and 2008. The research was conducted by a group of researchers from the Legislative Studies Center at UFMG. ${ }^{6}$ The aim of this project was to analyze the arguments and claims made about politics in Brazil using a different level of government, the states. The empirical strategy was to produce individual-level information, that is, deputies' opinions. This project has contributed to the debate on coalition formation in Brazil by overcoming the limits of roll call analysis. Surveys have never been used in such a way, and I believe they can add information that has been neglected so far.

It is hard to test the arguments I propose here using observational data on roll call voting. The result of an aggregation of votes does not tell us how the aggregation of preferences was produced as it only shows the final position taken by legislators. With my research strategy, I will be able to identify deputies' preferred relationships with other deputies, with the executive, with other partisan partners, and finally with their constituencies. This method circumvents the limits of roll call analysis, which only captures the last step of the relationship between legislators and the president. I overcome this limitation by using the deputies' expectations of their relationship with the president. By doing so, I hope to be identifying the mechanisms that tend to produce successful aggregation of majorities in legislative bodies as a function of the chief executive strategy to build them.

Of the 624 deputies that constituted the universe of analysis, 513 answered the questionnaire. This research project gained attention because of the lack of studies on subnational legislatives in Brazil and the need to produce an analysis that could contribute to the knowledge of the behavior, processes, and legislative law-making in the federated states. All political regions of Brazil were represented in the sample, including the following states: 
Table 1. Sample Description for State Assemblies Survey

\begin{tabular}{|c|c|c|c|c|}
\hline Region & State & Deputies & Sample Size & $\%$ \\
\hline \multirow{2}{*}{ North } & Para & 41 & 38 & 92.7 \\
\hline & Tocantins & 24 & 19 & 79.2 \\
\hline \multirow{3}{*}{ Northeast } & Bahia & 63 & 53 & 84.1 \\
\hline & Ceará & 46 & 41 & 89.1 \\
\hline & Pernambuco & 49 & 38 & 77.6 \\
\hline \multirow{2}{*}{ Center-West } & Goiás & 41 & 32 & 78.0 \\
\hline & MatoGrosso & 24 & 17 & 70.8 \\
\hline \multirow{3}{*}{ Southeast } & Minas Gerais & 77 & 63 & 81.8 \\
\hline & Rio de Janeiro & 70 & 53 & 75.7 \\
\hline & São Paulo & 94 & 77 & 81.9 \\
\hline \multirow{2}{*}{ South } & Rio Grande do Sul & 55 & 46 & 83.6 \\
\hline & Santa Catarina & 40 & 36 & 90.0 \\
\hline
\end{tabular}

Source: Survey with Legislators CEL-DCP 2008.

The questionnaire contained 112 questions and the answers were collected face-toface. The researchers involved in the project traveled to each state and interviewed all legislators in person at their offices. Appointments were made in order to guarantee availability for the interviews, which lasted around 40 minutes each. No one else was present in the office during the interviews. All personal information of legislators was undisclosed and no information was associated with specific names. All legislators signed an agreement allowing the researchers to conduct the interview under these conditions. All state legislators were contacted but some of them refused to participate in the research and, therefore, are not in the sample. To avoid selection bias in my results, I ran a logit model to check whether being in or out of the sample (dependent variable) was associated with any of my independent variables. None of the coefficients were statistically significant, which suggests that I am using a sufficiently randomized sample.

\section{The Dependent Variable: Strategy to Obtain Legislative Support}

The questionnaire had two questions that dealt specifically with the obtainment of legislative support. The first one concerned the way in which the governor negotiates with the legislature: with party leaders or individual legislators. The second question is about the kind of resources used by the governor to obtain legislative support: office positions or pork appropriations. In order to test my hypothesis I recoded both questions into one in such a way that all choices I am interested in were covered. ${ }^{7}$ The results are presented in Table 2. 
Table 2. Governor's Strategies to Obtain Legislative Support

\begin{tabular}{ccc} 
Strategies & $\mathrm{N}$ & $\%$ \\
\hline Others & 108 & 21.1 \\
Portfolio/Deputy & 54 & 10.5 \\
Pork/Party & 152 & 29.6 \\
Pork/Deputy & 82 & 15.9 \\
Portfolio/Party & 117 & 22.9 \\
\hline TOTAL & 513 & 100
\end{tabular}

Source: Survey with Legislators CEL-DCP 2008.

There is significant variation in the legislators' opinion of the most efficient strategy to obtain legislative support. Most members believe that the most efficient strategy is the negotiation of pork appropriations with party leaders, followed by portfolio negotiation with party leaders and negotiation of pork with individual legislators. The table also reveals the legislators' preference for negotiations involving party leaders: $52.4 \%$ of deputies believe this is the governor's best strategy to obtain legislative support. This evidence supports the argument that political parties also matter in subnational assemblies (Nunes 2009).

We can also observe variation of legislators' opinions by state assembly (see Figure 1). The deputies of the two largest states in Brazil, São Paulo (SP) and Minas Gerais (MG), believe the governor's best strategy to obtain legislative support is to negotiate pork with party leaders. Legislators from highly competitive states (Castro et al. 2009), such as Bahia (BA) and Rio Grande do Sul (RS), however, believe cabinet formation is the best strategy. In poor states like Ceará (CE) and Tocantins (TO), the negotiation of pork with individual legislators seems to be the most widely chosen option.

Figure 1. Governor's Strategies to Obtain Legislative Support by State

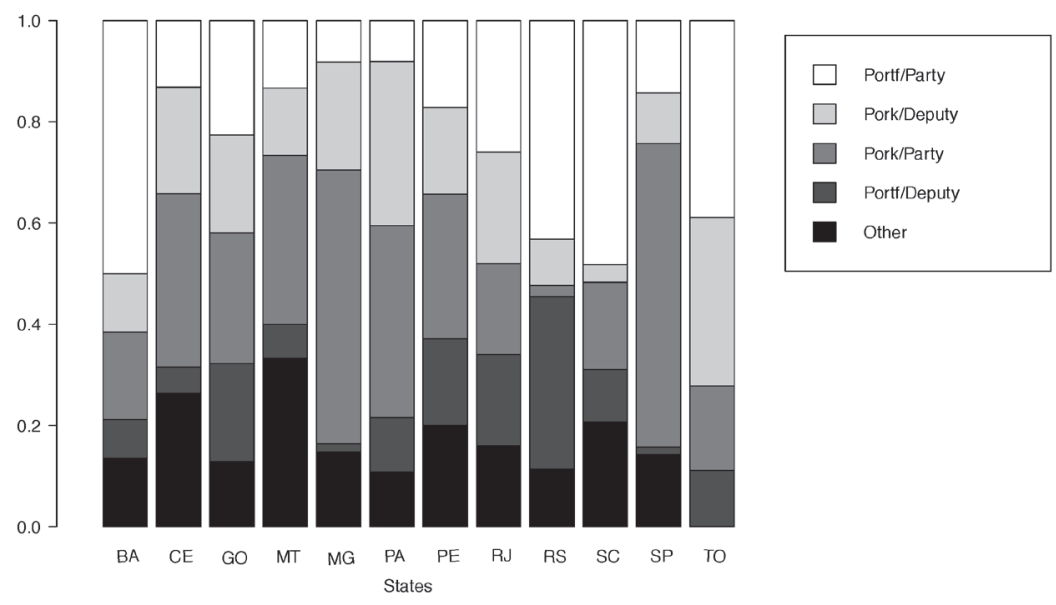


If there are different opinions regarding the strategies and resources offered in exchange for legislative support, then the governor must use different strategies to address various groups of potential allies. The challenge for the governor, therefore, is not to replicate what previous governments have done, but instead to follow a strategy that would give him the best utility in terms of legislative outcome. In order to match what is offered to the actors in each state political context, governors have to pay careful attention to actors' profiles. As I argue, they are the source of legislators' preferences for negotiation and resources. More importantly, it is not the offer that guarantees legislative success, but the acceptance of it.

\section{Independent Variables: Constituencies, Ideology and Party Centralization}

As previously indicated, I expect that legislators' opinions about the Executive's most efficient strategy to obtain legislative support will vary in three dimensions: (1) type of constituency, (2) degree of centralization of the political party, and (3) party ideological position. I believe that the combination of these factors would result in different types of optimal strategies for the governor, determining the composition of majorities, and the pattern of relationship between the Executive and the Legislative.

The first dimension explored in the questionnaire was the type of the legislators' constituency. Respondents had five options that were later recoded into three: (1) concentrated geographical constituency (concentrated constituency), (2) interest groups, and (3) the whole population of the district (scattered constituency). A geographical electorate is characterized by electoral support from specific areas within a district. They are usually sets of municipalities where legislators have had previous political experience, for instance, as a mayor. Constituencies of interest groups are formed around specific issues, and are typically composed of community leaders, unions, businessmen, churches, and other segments of society. A dispersed constituency is marked by a lack of specific identification with one or more groups or geographical areas. Legislators with dispersed constituencies typically have electoral support spread throughout the whole district. They are important and famous names in the party's list. The distribution of constituencies by state and party is presented in Figure 2. 
Figure 2. Distribution of Constituency Types by Brazilian States

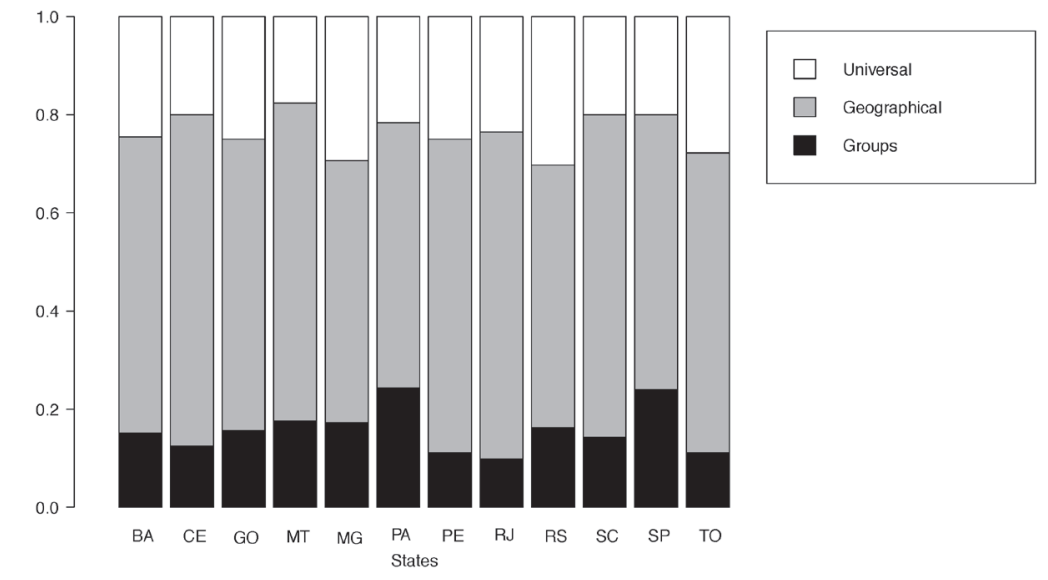

Figure 2 shows that the majority of members stated they were elected by geographical constituencies (57.7\%). This is true for all states investigated here. The remaining two categories have almost the same proportion of answers. Legislators with spread or dispersed constituencies represent $23 \%$ of the sample, whereas legislators linked to interest groups represent $19.3 \%$. These results are different from the ones obtained for the national Congress. Similar studies investigating the national Congress show the majority of national legislators with scattered constituencies (Ames 2001; Carvalho 2003; Nunes 2011). There is no reason to believe that legislators are misunderstanding the questions, nor that they do not know what kind of constituency they really represent. Unfortunately, there is no empirical work showing what kind of constituency state legislators have; therefore, I must assume that legislators are answering sincerely.

The second dimension explored in the questionnaire was the degree of political party centralization. Instead of directly asking whether leaders control parties, this aspect was measured by asking legislators to evaluate the power of their party leaders: weak, moderate, or strong. It is important to note that this question was not asked to party leaders, who made up $25 \%$ of the sample. I use their evaluations to classify centralized (strong leaders) and decentralized (weak leaders) party organizations. The distribution by state is presented in Figure 3. 
Figure 3. Distribution of Party Centralization by Brazilian States
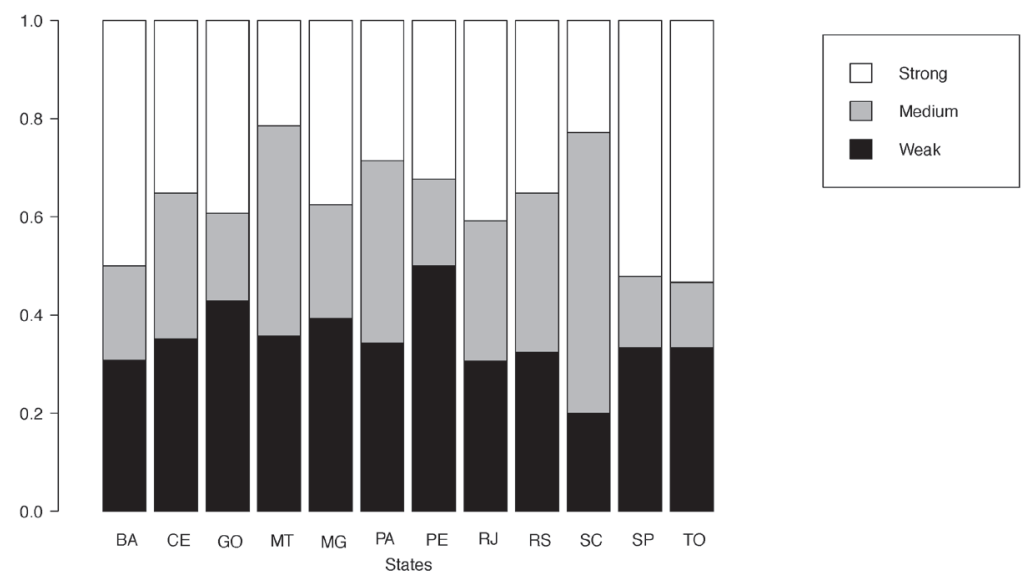

The variation of party centralization by state is also very interesting. Overall, legislators' perception of party centralization is split: $34.5 \%$ believe that their parties are decentralized while 39\% claim that party leaders are strong, and therefore their party is centralized. When I disaggregate information by state, we can see almost the same pattern. In several states, part of the legislators sees their parties as decentralized, and part as centralized. The largest differences are observed in Bahia (BA), Pernambuco (PE), and São Paulo. As this measurement is just an approximation of the centralization dimension that I want to study, I also checked the variation of the responses by party and state. The results show that, in general, legislators have cohesive perceptions about their party organizations. The standard deviation for each group is not very high. 
Figure 4. Distribution of Ideological Positions by Brazilian States
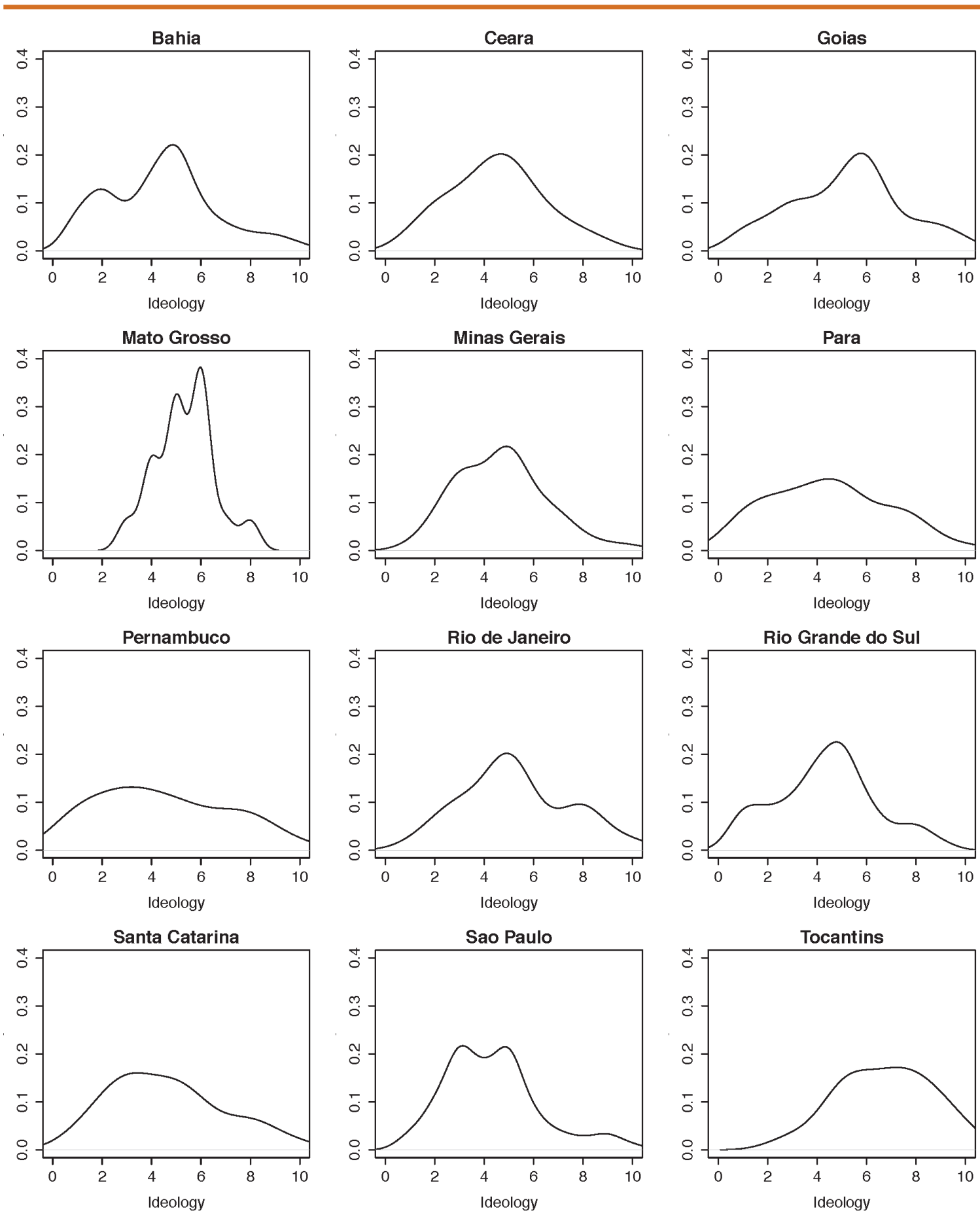

The last dimension explored in the questionnaire was the ideological position of legislators. In order to measure ideology, we built an ideological scale from 1 (left) to 10 (right), and asked legislators to position themselves on it. Other researchers interested in studying ideology in Brazil have also used such a strategy to capture inter- and intraparty variation (Castro et al. 2009; Melo and Nunes 2009; Power and Zucco Jr. 2009). Moreover, 
the continuous measurement of ideology provides a more granular measure than a discrete one (left-center-right).

The distribution of ideology by state is presented in Figure 4. The distributions are very similar to a classical normal curve. This implies that the majority of legislators position themselves at the center of the ideological distribution, highlighting their importance to a government coalition.

Figure 5. Ideological Positions of Relevant Parties in Brazilian States

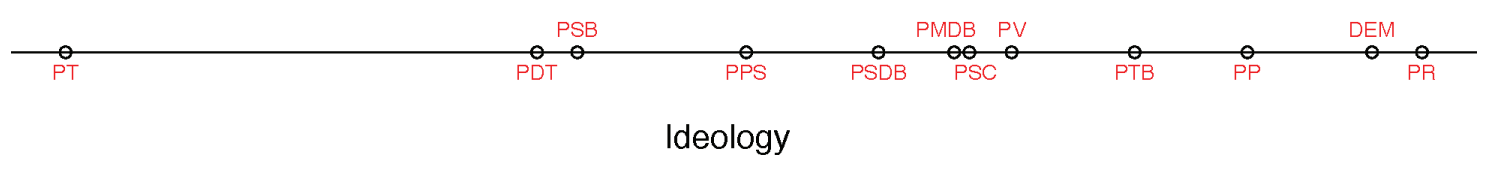

Figure 5 represents the average ideological position of the set of legislators for each political party. The distribution is very similar to the one presented in a paper about ideology in Brazil (Power and Zucco Jr. 2009). I excluded small parties from the figure as they do not contribute to the visualization of the information. After this exclusion, we see that PT is the furthest left-wing party on the spectrum, and PR is the furthest on the right.

So far, I have presented the main variables that I will be using in my analysis, but my model also includes other control variables: (1) government and opposition affinity, (2) type of relationship between government and opposition, (3) first term, (4) gender, and (5) schooling years. The summary of the variables is presented in Table 3 below.

Table 3. Summary Statistics

\begin{tabular}{|c|c|c|c|c|c|c|c|c|c|}
\hline & $\mathrm{N}$ & Mean & Std.Dev. & Min & Q1 & Median & Q3 & $\operatorname{Max}$ & Missing \\
\hline Strategy & 480 & 2.23 & 1.35 & 0 & 1 & 2 & 3 & 4 & 33 \\
\hline Centralization & 461 & 1.05 & 0.86 & 0 & 0 & 1 & 2 & 2 & 52 \\
\hline Relation Gov/Opp & 511 & 1.04 & 0.99 & 0 & 0 & 2 & 2 & 2 & 2 \\
\hline First term & 513 & 0.42 & 0.49 & 0 & 0 & 0 & 1 & 1 & 0 \\
\hline Gender & 513 & 1.12 & 0.33 & 1 & 1 & 1 & 1 & 2 & 0 \\
\hline
\end{tabular}




\section{Multinomial Logit Model}

When a dependent variable is discrete (such as governor's strategy to obtain legislative support), OLS estimation is not appropriate because basic assumptions of OLS are violated, as shown by Pindyck and Rubinfeld (1981) and Greene (2008). To avoid these problems, researchers convert the discrete variable - the executive's strategy for dealing with legislators, in this case - into a continuous variable, such as the probability of preferring one strategy to another. The next step is to choose an appropriate functional form to estimate this probability. A linear probability model may underestimate the true regression slope when there are many observations characterized by extreme values of choice probability ( 0 and 1$)$. This specification bias cannot be corrected by using a nonlinear estimation procedure, however. Given that all probabilities lie between 0 and 1, the use of the cumulative probability function should provide the most acceptable transformation.

Because the number of strategies available to governors to obtain legislative support (my dependent variable) is greater than four, a multinomial qualitative model would render useful information that is somewhat different from that obtained in binary logit or probit models. Therefore, I could choose to implement either a multinomial logit or probit model. The multinomial probit has some attractive features, including a normally distributed error term, easily interpreted results, and the provision of general patterns of cross-elasticity (King 1998; Greene 2008; Wooldridge 2010). However, the multinomial probit can be applied only when there is a small number of alternatives (usually three) because for categories of four or more, numerical integration is too costly for practical application in iterating likelihood maximization (McFadden 1984). For example, multivariate integrals are required for many alternatives. Therefore, this technique may not be appropriate to analyze the determinants of a governor's strategy as this would involve five different categories in this analysis.

On the other hand, given its relative computational ease, multinomial logit has been widely used, even though the error term has a logistic distribution and the restrictions of the "independence of irrelevant alternatives" assumption (Wooldridge 2010). My goal in this paper is to use the multinomial logit (MNL) model to identify the major determinants of the opinions that legislators have concerning the governor's strategies to achieve legislative success.

Let $y$ denote a random variable taking on the values $\{0,1, \ldots, J\}$ where $J$ is a positive integer, and let $\mathbf{x}$ denote a set of conditioning variables. For example, if $y$ denotes governor's strategies to obtain legislative support, $\mathbf{x}$ can contain things like constituency type, ideology, political parties centralization and gender. I assume that $\left(x_{i}, y_{i}\right)$ is a random draw from the population. As in binary response models, we are interested in how changes in 
the elements of $\mathbf{x}$ affect the response probabilities, $\mathrm{P}(y=j \mid \mathbf{x}), j=0,1,2, \ldots ., J$. Since the probabilities must sum to $1, \mathrm{P}(y=0 \mid \mathbf{x})$ is determined once we know the probabilities for $j=1, \ldots . J$. Let $\mathbf{x}$ be a 1 times $\mathrm{K}$ vector with first element unity. The multinomial logit model (MNL) has response probabilities

$$
P(y=j \mid x)=\frac{\exp \left(x b_{j}\right)}{1+\prod_{h=1}^{j} \exp \left(x b_{h}\right)}
$$

where $\mathrm{b}_{\mathrm{j}}$ is $\mathrm{K}$ times $1, j=1, \ldots ., \mathrm{J}$. And because the response probabilities must sum to 1 ,

$$
P(y=0 \mid x)=\frac{1}{1+\square_{h=1}^{J} \exp \left(x b_{h}\right)}
$$

when $J==1, \mathrm{~b}_{1}$ is the $\mathrm{K}$ times 1 vector of unknown parameters, and we get the binary logit model.

We estimate the model by forming the log likelihood function

$$
\ln L=\square_{i} \mathrm{~d}_{\mathrm{i} j} \ln P(\mathrm{y}=\mathrm{j})
$$

where $\mathrm{d}_{\mathrm{ij}}=1$ if person $i$ made choice $j$ and is 0 otherwise.

In this paper $J$ can take five values $\{0,1,2,3,4\}$ respectively: other strategies (A), negotiation of portfolios with deputies (B), negotiation of pork with party leaders (C), negotiation of pork with deputies (D), and negotiation of portfolios with party leaders (E). Then, we estimate the log of the odds of one strategy versus another as a linear function of the explanatory variables.

\section{Empirical Results}

The empirical results of the multinomial logit estimation are shown in Table 3. To make interpretation easier, I have calculated the log-odds for the substantive comparison that I want to make here, i.e. the comparison between D, negotiation of pork with deputies, and E, negotiations of portfolios with party leaders (see last column in Table 4). Formally speaking, such comparison is possible given that the coefficients that we estimate using the MNL method can be interpreted as the effects on the log of the odds ratio between 
each given category and the excluded category. Therefore, we can find the difference between two categories by subtracting their log-odds from one to another (Greene 2008).

Table 4. Multinomial Logit Model Coefficients (Log-odds)

\begin{tabular}{cccccc} 
& Portfolio & Pork & Pork & Portfolio & \multirow{2}{*}{ C/D } \\
& Deputy (A) & Leader (B) & Deputy (C) & Leader (D) & \\
\hline Concentrated & 0.19 & -0.04 & 0.14 & -0.97 & 1.18 \\
\hline constituency & $(0.68)$ & $(0.49)$ & $(0.57)$ & $(0.48)$ & $(0.64)$ \\
\hline Scattered & & & & & \\
\hline constituency & 0.20 & -0.65 & -0.44 & -0.92 & 0.58 \\
\hline Party & $(0.73)$ & $(0.56)$ & $(0.63)$ & $(0.52)$ & $(0.78)$ \\
\hline centralization & & & & & \\
\hline Ideology & 0.34 & -0.14 & 0.10 & -0.21 & 0.33 \\
\hline & $(0.24)$ & $(0.18)$ & $(0.21)$ & $(0.20)$ & $(0.22)$ \\
\hline & -0.08 & & & 0.04 & 0.13 \\
\hline & $(0.11)$ & $(0.09)$ & $(0.09)$ & $(0.09)$ & $(0.09)$
\end{tabular}

Standard Errors are in parenthesis. All controls are included (deputy position in regard to the government, type of competition between government and opposition, first term, gender, and school years) and each regression includes state fixed effects.

Log-odds for Portfolio-leader/Pork-deputy estimated by non-parametric bootstrap in R 2.15 .

The MNL model predicts that legislators with concentrated constituencies tend to believe the best strategy for the governor to obtain legislative support is to negotiate pork with individual deputies. The model also predicts that legislators with scattered constituencies tend to believe that the governor's best strategy to obtain legislative support is by means of negotiating portfolios - meaning building a multiparty cabinet. The centralization of a political party is associated with strategy A, negotiation of portfolios with deputies. Finally, conservative legislators tend to prefer negotiations of pork. The general outcome for constituency and ideology is consistent with my expectations, but the effect of centralization is not strong enough to be conclusive (see Table 4).

But more important than the results of the four first columns in Table3 is the direct comparison between the negotiation of pork with deputies and the negotiation of portfolios with party leaders (see column C/D in Table 4). The reason being the literature on executive-legislative relations in Brazil has shown that these two strategies are the most common strategies that presidents have used to build their coalitions (Aleman and Tsebelis 2002; Altman 2000; Ames 2001; Amorim Neto 2006a; Amorim Neto and Santos 2003; 
Figueiredo and Limongi 1999; Inacio 2006; Morgenstern 2004; Nunes 2011; Pereira and Mueller 2004; Santos 2003; Raile et al. 2010; Zucco Jr. 2009).

The results for the direct comparison between the negotiation of pork with deputies and the negotiation of portfolios with party leaders suggest that legislators prefer the first option over the second if they have a concentrated constituency, are members of centralized parties, and classify themselves as conservatives. Excluding the centralization effect again, the other two variables correlate with the governor's strategies as expected. Although the magnitude and direction of such coefficients are related to my theory, the confidence intervals are too large, decreasing the accuracy of my estimations. This is likely due to the size of my sample as I set the model for each category. A substantive interpretation of such results, then, is a better approach for understanding the relevance of these outcomes.

Next, I analyze the likelihood of the legislators' preferences given different values of ideology and centralization, and excluding the fixed effects for each state. As Figure 6 shows, left-wing legislators believe that the governor's best strategy to obtain legislative support is to negotiate portfolios, but only when their constituencies are scattered. The attitude towards party leaders is stronger among deputies in general, but it is especially strong among right-wing deputies. This result shows the predominance of ideological position over constituency and party structure in predicting legislators' opinions about the ideal type of relationship with governors. The exception, however, is the group of left-wing legislators with scattered constituencies and centralized parties. For them, negotiations of portfolio are better and should be pursued between individual deputies and the government. For conservatives, on the other hand, the most efficient way for a governor to obtain legislative support is by negotiating pork with party leaders. This result contradicts the conventional wisdom, as a large part of the literature does not claim such strategy. Therefore, it looks like party leaders are very important actors in right-wing parties as they are seen as efficient brokers between governors and deputies. 
Figure 6. Marginalized Predicted Probabilities of Legislators' Preferences about Governor's Strategies to Obtain Legislative Support

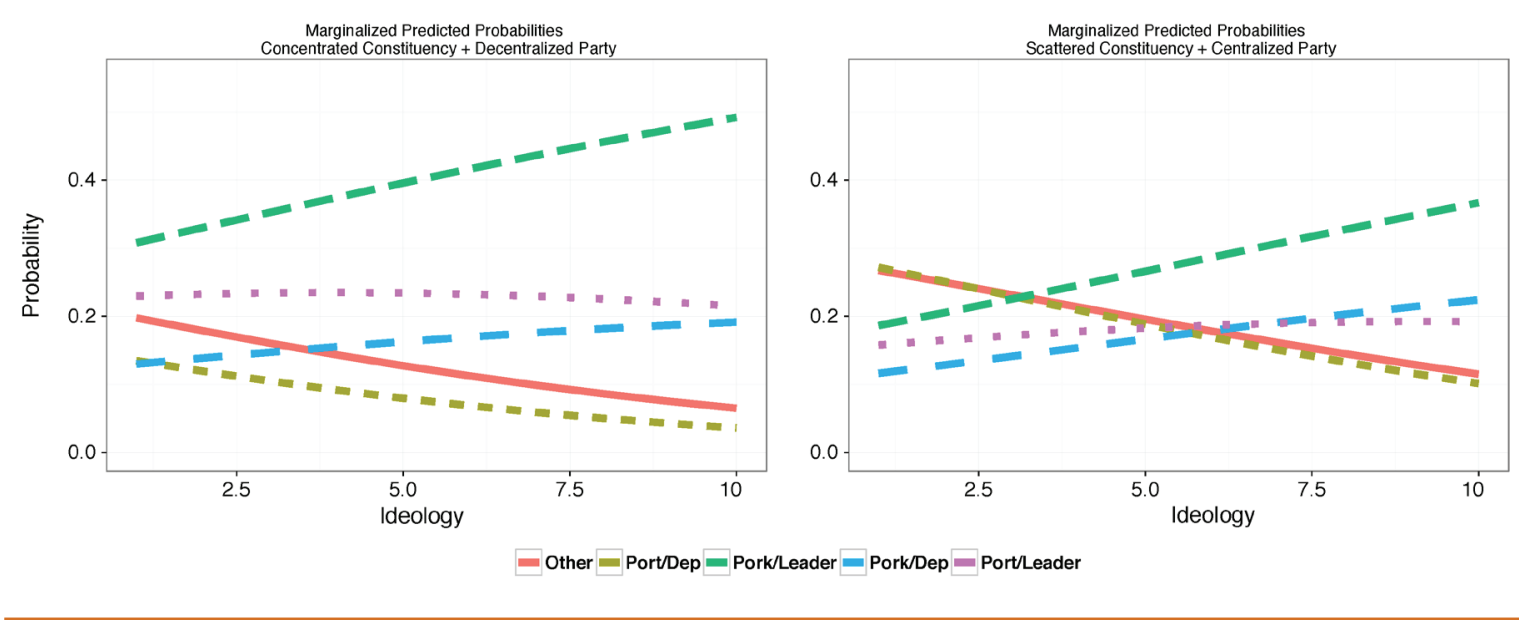

In the comparison of strategies C (blue line) and D (purple line), we observe that conservative legislators with concentrated constituencies tend to prefer negotiations of pork much more often than conservative legislators with scattered constituencies. Portfolio is preferred as a resource by deputies with scattered constituencies a lot more than by deputies with concentrated constituencies. In the case of legislators with scattered constituencies and members of centralized political parties, it is remarkable how the lines of portfolio/deputy and pork/deputy cross each other, suggesting, again, the preference of pork by right-wing legislators, and the preference of portfolios by left-wing deputies. It also calls the attention the fact that the strategy pork/deputy is considered more effective by deputies from right-wing parties with scattered constituencies.

In general, Figure 6 shows that depending on the combination of certain features of political profiles, we should expect different utilities from legislators as measured by their opinions/preferences. Conservatives with concentrated constituencies tend to prefer party negotiations involving pork. Liberals representing interest groups are more satisfied with cabinet formation. Moderates in centralized parties prefer negotiations of pork with party leaders. Representatives of scattered coalitions identified as conservatives prefer party negotiations for pork. And finally, liberal legislators that represent regional interests are more prone to accept supporting the governor when pork is negotiated with party leaders.

What do these results suggest after all? First, the three dimensions explored in this work affect the probability of a parliamentary opinion on the governor's best strategy to obtain legislative support. As expected, the profile of legislators seems to influence their opinions about the relationship with the executive. This may imply, consequentially, that the profile of deputies also influences the utility functions of legislators when negotiating 
support with the governor. Thus, the findings support the argument that there is variation to be explained regarding not only the relationship between the executive and the legislature but also the achievement of successful coalitions. Second, although I have not explored an additional plausible strategy - namely the negotiation for policies rather than resources (Cheibub et al. 2004) - , it seems credible to assert that resources and policies can have different effects on players' preferences. It will be profitable to investigate how in future research.

\section{Final Considerations}

This paper examined the hypothesis that the opinion legislators form about the most efficient strategy for a governor to obtain legislative support is linked to his political profile. Rather than explaining the composition of a government coalitions only through the lens of its own characteristics, such as ideological contiguity, size of opposition, number of parties, or different types of offices, this paper has shown that governors must concern themselves with the characteristics of their potential allies in coalitions as well. Studying the legislators' profiles can help governors to build efficient coalitions, where more political support is gained for a lower price.

Another contribution of this paper relies on the estimates provided by a multinomial logit model using survey data from legislators in Brazilian State Assemblies. There are several benefits of using a survey for this kind of analysis and the most salient is to overcome the limits of roll call data. With a survey, the researcher captures better the sincere preference of legislators, something almost impossible to obtain from roll call votes. The survey also allows the researcher to create specific questions to capture nuances that have empirical and theoretical importance. By using roll calls, a researcher is limited to examining the legislator's ex post facto preferences.

The first interesting pattern I presented concerned the variation of legislator's opinions on the governor's best strategies to obtain legislative support. Although a majority prefers negotiations of pork with party leaders, all five categories have similar proportions. The analysis also called the attention to the importance that legislators ascribe to political parties. More than $50 \%$ of legislators believe that parties are the best way to successful negotiations between the Executive and the Legislative. In future research, I would like to investigate the residual strategies that were recoded into one category.

Next, I described the distribution of the legislators' constituency types, the levels of party centralization and the ideological position in every state investigated. I observed very similar patterns for each variable. I was especially impressed with the distribution of ideology across all twelve states. Almost all cases approach a normal distribution, with 
radical positions being rare in the assemblies. The classification of parties into one unique dimension also deserves to be highlighted. As many other studies on ideology in Brazil have noted, both the classification and the ordering of parties seems to be very stable.

Finally, I tested three hypotheses about the possible relationships between legislators' profiles and their attitudes regarding the governors' strategies to negotiate legislative support. Except for party centralization, all remaining hypotheses could not be rejected based on the available data. First of all, members of dispersed constituencies that self-classified themselves as liberals are more likely to believe that the best governor's strategy to obtain legislative support is to negotiate portfolios with party leaders. Liberal legislators from concentrated constituencies, on the other hand, are more likely to prefer individual negotiations for pork. Party centralization, contrary to what I expected, tends to be associated with negotiations involving pork and individual legislators, not portfolios and leaders.

In conclusion, my results point towards an analytical perspective that takes into account not only discrete choices, but interactive ones as well. Instead of seeing presidents or governors as players trying to maximize one or the other strategy, my empirical outcomes suggest that they do both at the same time. Pork is more efficient for some allies whereas portfolios are more useful to others. Some prefer direct negotiations and others believe that the best strategy to build a successful coalition is to form a multiparty cabinet. In other words, different allies are attracted by different offers, therefore this leads executives to choose optimal strategies for different negotiations. This result directly contradicts the notion that only one strategy prevails in all cases. The received wisdom from the existing literature missed most of the complexity that involves negotiations between the executive and the legislature, especially in fragmented party systems.

Revised by Sandra Gomes Submitted in August 2011

Accepted in June 2012

\section{References}

Aldrich, J. 1995. Why Parties? The Origin and Transformation of Political Parties in America. Chicago: University of Chicago Press, 1 edition.

Alemán, Eduardo and George Tsebelis. "Political Parties and Government Coalitions in the Americas," Journal of Politics in Latin America, 3 (1): 3-28, 2011.

Altman, D. 2000. "The politics of coalition formation and survival in multiparty presidential democracies: The case of Uruguay, 1989-1999". Party Politics, 6:259-283.

Ames, B. 2001. The Deadlock of Democracy in Brazil. Michigan: University of Michigan Press. 
Amorim Neto, O. 2006a. Presidencialismo e Governabilidade nas Américas. Rio de Janeiro: Editora da FGV.

Amorim Neto, O. 2006b. "The presidential calculus: Executive policy making and cabinet formation in the Americas". Comparative Political Studies, 39(4):415-440.

Amorim Neto, O. and Santos, F. 2003. "O segredo ineficiente revisto: O que propõem e o que aprovam os deputados brasileiros". Dados — Revista de Ciencias Sociais, 46(4):661-698.

Campbell, S., Fowles, E., and Weber, B. 2004. "Organizational structure and job satisfaction in public health nursing". Public Health Nursing, 21(6):564-571.

Carvalho, N.R. 2003. E no Início Eram as Bases: Geografia política do voto e comportamento legislativo no Brasil. Rio de Janeiro: Editora Revan.

Castro, M.M.M., Anastasia, F., and Nunes, F. 2009. "Determinantes do comportamento particularista de legisladores estaduais brasileiros". Dados - Revista de Ciencias Sociais, 52(4):961-1001.

Cheibub, J.A., Przeworski, A., and Saiegh, S. 2004. "Government coalitions and legislative success under parliamentarism and presidentialism". British Journal of Political Science, 34(3):284312.

Cohen, M., Karol, D., Noel, H., and Zaller, J. 2008. The Party Decides: Presidential Nominations Before and After Reform. Chicago: Chicago University Press.

Cox, G. 2005. "The organization of democratic legislatures". In: B. Weingast and D. Wittman, editors, The Oxford Handbook of Political Economy. Oxford: Oxford University Press.

Figueiredo, A. and Limongi, F. 1999. Executivo e Legislativo na Nova Ordem Constitucional. Rio de Janeiro: Editora da FGV.

Glisson, C and Durick, M. 1988. "Predictors of job satisfaction and organizational commitment in human service organizations". Administrative Quarterly, 33:61-81.

Greene, W. 2008. Econometric Analysis. Pearson, 6th edition.

Inácio, M. 2006. "Entre presidir e coordenar: Presidência e gabinetes multipartidários no Brasil". In: III Congress of the Latin American Political Science Association (ALACIP). ALACIP, Campinas, Brasil.

Iversen, T. and Soskice, D. 2006. "Electoral institutions and the politics of coalitions: Why some democracies redistribute more than others". American Political Science Review,100(2).

King, G. 1998. Unifying Political Methodology. Michigan: The University of Michigan Press, $2^{\text {nd }}$ edition.

Limongi, F. 2006. "Presidencialismo, coalizão partidária e processo decisório". Novos Estudos, 76:17-41.

Mair, P. 2006. "Political parties and party systems. In: P. Graziano and M. Vink, editors, Europeanization: New Research Agendas. New York: Palgrave MacMillan.

McCarty, N., Poole, K., and Rosenthal, H. 2008. Polarized America. Cambridge: MIT Press. 
McFadden, D. 1984. "Econometric analysis of qualitative response models". In: Z. Griliches and M. Intriligator, editors, Handbook of Econometrics. London: North-Holland Press.

Melo, C.R. and Nunes, F. 2009. "Ideologia e distancia de preferências: Uma comparação dos governos Lagos e Lula". In: M. Inácio and L. Renno, editors, Legislativo Brasileiro em Perspectiva Comparada, pp. 381-408. Belo Horizonte: Editora UFMG.

Morgenstern, S. 2004. Patterns of Legislative Politics: Roll-Call Voting in Latin America and the United States. Cambridge: Cambridge University Press.

Mueller, W. and Strom, K. 1999. Policy, office, or votes: How political parties in Western Europe make hard decisions. Cambridge: Cambridge University Press.

Nunes, F. 2009. Governos de Coalizão e Resultados de Soma Positiva em Minas Gerais e no Rio Grande do Sul 1999-2006. Master's thesis, Universidade Federal de Minas Gerais.

Nunes, F. 2011. "The conditional effect of pork: How does the geography of constituencies affect legislative behavior in Brazil?" In: Annual Meeting of Southern Political Science Association.

Pereira, C. and Mueller, B. 2004. "The cost of governing: Strategic behavior of the president legislators in Brazil's budgetary process". Comparative Political Studies, 37(7):781-815.

Pindyck, R. and Rubinfeld, D. 1981. Econometric models and economic forecasts. Michigan: McGraw-Hill, 2nd edition.

Power, T. and Zucco, Jr, C. 2009. "Estimating ideology of Brazilian legislative parties, 1990-2005". Latin America Research Review, 44(1).

Raile, E., Pereira, C., and Power, T. 2010. "The executive toolbox: Building legislative support in a multiparty presidential regime". Political Research Quarterly, 10(20):1-12.

Saiegh, S. 2004. Government Defeat: Coalitions, Responsiveness, and Legislative Success. Ph.D. thesis, New York University.

Santos, F. 2001. O Poder Legislativo nos Estados: diversidade e convergência. Rio de Janeiro: Editora da FGV.

Santos, F. 2003. O Poder Legislativo no Presidencialismo de Coalizão. Belo Horizonte: Editora da UFMG.

Sartori, G. 1987. The Theory of Democracy Revisited, volume 2. Virginia: Chatham House Publishers.

Silame, T. 2006. O sistema comissional na Assembléia Legislativa de Minas Gerais. Master's thesis, Universidade Federal de Minas Gerais.

Souza, C. and Dantas Neto, P. 2006. Governo, políticas públicas e elites políticas nos estados brasileiros. Rio de Janeiro: Editora Revan.

Strom, K. 1990. Minority Government and Majority Rule. Cambridge: Cambridge University Press.

Weingast, B. and Marshall, W. 1988. "The industrial organization of congress; or, why legislatures, like firms, are not organized as markets". The Journal of Political Economy, 96(1):132-163. 
Wooldridge, J. 2010. Econometric Analysis of Cross Section and Panel Data. Cambridge: Cambridge Press, 2nd edition.

Zucco Jr, C. 2009. "Ideology or what? Legislative behavior in multiparty presidential settings". The Journal of Politics, 71(3): 1076-1092.

\section{Notes}

1 The survey was conducted by the Legislative Studies Center at UFMG-Brazil. I collaborated with this research as a graduate student at UFMG.

2 For studies on subnational governments in Brazil see de Castro et al. (2009), Lima Jr. (1997), Nunes (2009), Santos (2001), Silame (2006), Souza and Dantas Neto (2006).

3 It is important to say that there are differences in the percentiles between the states throughout time, but, in general, the pattern observed is a significant amount of legislative success (Nunes 2009; Santos 2001; Silame 2006; Souza and Dantas Neto 2006).

4 See Inacio (2006) for a discussion of the Brazilian case.

5 Ames (2001), Pereira and Mueller (2004), and Zucco Jr. (2009) assert that Brazilian presidents exchange patronage and pork with legislative support, but they did not pay attention on the limits of such a strategy.

6 I thank professors Fatima Anastasia, Magna Inacio, Carlos Ranulfo de Melo and Monica Mata Machado de Castro for allowing me to use the dataset.

7 The questionnaire also covers other possibilities for negotiations and resources, but due to the low percentage of answers to these questions, and no academic interest in relation to them, I chose to include them in the category "others". 